\title{
Physico-chemical properties, spreadability and consumer acceptance of low-sodium cream cheese
}

\author{
Mirela Lučan ${ }^{*}$, Jasmina Ranilović2, Vedran Slačanac', \\ Tanja Cvetković ${ }^{2}$ Ljiljana Primorac', Davorka Gajari², \\ Helena Tomić Obrdalj², Marko Jukićn, Jasmina Lukinac Čačićp
}

\footnotetext{
'Josip Juraj Strossmayer University of Osijek, Faculty of Food Technology Osijek, Franje Kuhača 20, 31000 Osijek, Croatia ${ }^{2}$ Research and Development, Podravka Ltd. Ante Starčevića 32, 48000 Koprivnica, Croatia

$+{ }^{*}$ Corresponding author: mlucan@ptfos.hr
}

\section{Abstract}

The present study was performed to investigate the possibility of sodium reduction in cream cheese by partial reduction and substitution of sodium by potassium based salt. Four salt treatment were selected by preliminary study: $100 \% \mathrm{NaCl}$ (control), $\mathrm{NaCl}$ reduced to $65 \%$ (T1), $35 \%$ of NaCl substituted by $\mathrm{KCl}$ (T2), and $\mathrm{KCl}$-based salt mixture Salut ${ }^{\oplus}$ which contains offflavours masking compound (T3). The study was evaluated physico-chemical attributes, colour, spreadability, sensory acceptance, as well as level of intensity of specific attributes of low-sodium cream cheese. Sodium reduction not influenced on the protein, fat and moisture content, water activity, acidity and the colour of cream cheese $(P>0.05)$. However, sodium reduction significantly influenced to mineral composition, spreadability and sensory properties. The use of potassium salt substitutes significantly increased the value of K:Na ratio. Cheese containing commercial salt replacer Salut ${ }^{\oplus}$ had the closest hedonic score to control cheese compared to other replacers. The current research demonstrates that sodium content can be reduced by $35 \%$ in cream cheese using a nutritionally valuable potassium-based salt mixture, without compromising the consumer acceptance.

Key words: cream cheese, sodium reduction, potassium chloride, spreadability, sensory analysis

\section{Introduction}

Sodium is an essential nutrient naturally found in a variety of foods. It is the major extracellular cation with important role in the body: regulates blood pressure, and electrolyte and fluid balance, helps nerve cells and muscle cells activity etc. (StrazzuIlo and Leclercq, 2014). Although the minimum physiological need for sodium is not defined, it is estimated to be 200-500 mg per day, or about 0.51.25 grams of salt per day (WHO, 2012). The intake of sodium in modern Western diet is generally excessive, between 3 and 6 grams of sodium per day, which is well above 2 grams of sodium per day (equivalent to 5 grams of salt per day) recommended by WHO/FAO (WHO/FAO, 2003). In Croatia, an adult has an average daily intake of $11.6 \mathrm{~g}$ of table salt (CFA, 2014). Increasing sodium intake is related 
to increased risk of cardiovascular diseases such as hypertension, coronary disease and stroke (O'D onnell et al., 2015). A number of strategies and recommendations for salt reduction at the global as well as at the national level exist (Government of the Republic of Croatia, 2014; WHO, 2012). One of the goals of the European Food and Nutrition Action Plan for the period from 2015 to 2020 is to reduce the mean population intake of salt and sodium by $30 \%$ (WHO, 2014).

Most of the daily salt intake is originating from processed foods (70-75\%), while only 10-15\% from natural food, and 10-15\% from discretionary salt added during cooking and eating (EFSA, 2006). In most of the European countries, major food groups which contribute mainly to sodium intake are bread and bakery products, cereal products, meat and meat products, cheese and dairy products as well as ready meals and soups (EC, 2012). Dairy foods are important nutrients sources, including calcium, magnesium and potassium. Increasing dairy consumption is associated with improved bone health, especially in children and adolescents, reduced cardiovascular disease and type 2 diabetes, and lower blood pressure in adults (Rice et al., 2013). Due to benefits of milk and milk products, current dietary guidelines recommend at least two up to four servings (standard serving sizes are a glass of milk, a cup of yoghurt, a slice of cheese, teaspoon of butter) of fat-free or low-fat dairy products daily (Dehghan et al., 2018). Production and consumption of dairy products, especially cheeses and spreadable dairy products, has been growing rapidly over the past few years (Lactimed, 2015) with the trend of further growth in the next decade (OECD/FAO, 2016).

The contribution of milk, yoghurt, ice cream and dairy desserts to dietary sodium is low, but cheese and dairy spreads can contain significant amounts of sodium and significantly contribute to daily sodium intake.

Cream cheese is a fresh, soft cheese manufactured by acid coagulation of cream or a mixture of milk and cream with mesophilic starter cultures. Due to its spreadable texture, mild and creamy aroma, except as a spread on the bread, cream cheese is increasingly used as salad dressing, cake filler, cooking condiment, butter/margarine substitute etc. Cream cheese is characterised by lower salt contents (0.8-1.3\% salt; (FSA, 2006; Phadungath,
2005)) in comparison to brined cheeses and most semi-hard and hard cheeses. However, since it is consumed almost daily because of its versatile usability, its contribution to dietary sodium intake can be significant.

Salt in cheesemaking generally has two main functions: it acts as preservative and contributes to the taste of cheese. Salt in cheese influences on the water activity $\left(\mathrm{a}_{\mathrm{w}}\right)$, regulating thereby microbial growth and enzyme activity, protein hydration and biochemical changes. All these salt effects eventually influence the flavour, aroma, texture, safety and overall quality of cheese (Guinee, 2004). Strategies for reducing the content of sodium in cheese include lowering the amount of added salt, partial or complete substitution of $\mathrm{NaCl}$ by other salts such as $\mathrm{KCl}, \mathrm{MgCl}_{2}$ or $\mathrm{CaCl}_{2}$, in combination with flavour enhancers or/and bitterness blockers and modification in cheesemaking processes (Bae et al., 2017; Cruz et al., 2011). The most important salt substitute is $\mathrm{KCl}$ : it provides similar salty taste like $\mathrm{NaCl}$, but with unpleasant bitter, chemical and metallic off-tastes. This can be successfully overcome with the addition of flavour enhancer (Cepanec et al., 2017b) and promising results has been recently published relating $\mathrm{KCl}$ based innovative salt substitute application in soups (Ranilović et al., 2019). Other mineral salts have undesirable flavour that limit their use. Apart from reducing sodium intake, another advantage of potassium-based substitution is hearthealthy benefits of this shortfall nutrient (Weaver, 2013).

Several studies have been carried out on the possibility of reducing salt in Cheddar (Khetra et al., 2016; Khetra et al., 2019; McCarthy et al., 2016), Feta (Katsiari et al., 1997; Katsiari et al., 2000), Mozzarella (Ayyash and Shah, 2011; Rodrigues et al., 2014), processed cheese (Mozuraityte et al., 2019; Nogueira et al., 2018) and some local types of cheese (Akan, 2018; Costa et al., 2018; Katsiari et al., 1998). However, there is few information about effect of the reduced sodium content on cream cheese quality (Wendin et al., 2000). The present study evaluated the ability of sodium level reduction in cream cheese using partial reduction, partial substitution with potassium chloride and substitution with salt replacer mixture. The effects of mentioned reductions on chemical, textural and sensory properties of cream cheese were also investigated. 


\section{Materials and methods}

\section{Preliminary study: Low-sodium cream cheese recipe development}

Preliminary study was conducted to develop and testing various formulation of cream cheese in which salt had been partially reduced or substituted by salt mixture.

For the preliminary study, cream cheese was produced unsalted in a local dairy plant, and then salted in laboratory conditions. Sodium content in cream cheese samples was reduced to $25 \%$, $35 \%$ and to $50 \%$. Reduction was conducted by partial reduction of added salt, partial substitution with potassium chloride, and partial substitution with commercially available salt substitutes. The salts used in the study were food grade sodium chloride, food grade potassium chloride, and commercial salt replacer mixtures: Salut ${ }^{\oplus}$ (Podravka Ltd.; Croatia), an innovative mineral salt blend with 35 $\%$ less sodium (Cepanec et al., 2017b); LowNat Salt (Raab Vitalfood GmbH, Germany), a mineral salt mixture with $50 \%$ less sodium; and Vital Salt (Salinen Austria AG, Austria), salt with $50 \%$ less sodium (Table 1). All samples were prepared $24 \mathrm{~h}$ before the experiment and stored in hermetically sealed plastic containers ( $150 \mathrm{~g}$ portions) at $4{ }^{\circ} \mathrm{C}$.

Scoring method was conducted for evaluation of compliance of prepared low-sodium cream cheese samples (TO-T7) with the standard cream cheese specifications. The sensory evaluation of appearance, colour, odour, taste and consistency of low-sodium cream cheese samples was conducted according to the 20-point scoring method with weighted factors (Filajdić et al., 1988; ISO/IDF, 2009) by a panel of seven trained assessors. Panellist rated each sensory attribute using a 5-point scale ( 1 = unsatisfactory, 2 = less satisfactory, 3 = satisfactory, 4 = good, 5 = excellent). Overall sensory quality of samples was expressed as the sum of the products of scores for each attribute multiplied with specified weighted factor (appearance 0.2, colour 0.4 , odour 0.6 , taste 2.0 , consistency 0.8 ).

The triangle test was conducted to determine whether there was a difference between control and prepared low-sodium cream cheese samples (TO-T7). The triangle test was performed by a trained panel (36 faculty members and students) according to ISO:4120 (ISO, 2004). Samples of cream cheese (approximately $10 \mathrm{~g}$ ) were placed into transparent plastic cups labelled with random 3-digit identification codes. Low-sodium cream cheese was presented against control cheese in a series of eight triangle tests.

\section{Cream cheese production}

The cream cheese was produced in a Belje plus Dairy, Darda, Croatia according to manufacturer's specification for ABC cream cheese. Briefly, cream standardized to a fat content of $10 \%$ was incubated with mesophilic starter at $24^{\circ} \mathrm{C}$. The fermentation process was ended by pasteurization, when

TABLE 1. Control and reduced-sodium cream cheeses with various combination of salt treatments and salt composition

\begin{tabular}{l|l|l|l}
\hline Code & Salt treatment & Salt composition & $\begin{array}{l}\text { Level of } \\
\text { sodium } \\
\text { reduction }\end{array}$ \\
\hline Control & Standard & $100 \% \mathrm{NaCl}$ & $0 \%$ \\
\hline T0 & Partial salt reduction & $75 \% \mathrm{NaCl}$ & $25 \%$ \\
\hline T1 & Partial salt reduction & $65 \% \mathrm{NaCl}$ & $35 \%$ \\
\hline T2 & Partial substitution with $\mathrm{KCl}$ & $65 \% \mathrm{NaCl}+35 \% \mathrm{KCl}$ & $35 \%$ \\
\hline T3 & Total substitution by commercial salt replacer mixture & $100 \% \mathrm{Salut}$ & $35 \%$ \\
\hline T4 & Partial salt reduction & $50 \% \mathrm{NaCl}$ & $50 \%$ \\
\hline T5 & Partial substitution with $\mathrm{KCl}$ & $50 \% \mathrm{NaCl}+50 \% \mathrm{KCl}$ & $50 \%$ \\
\hline T6 & Total substitution by commercial salt replacer mixture & $100 \% \mathrm{LowNat}{ }^{\mathrm{TM}}$ & $50 \%$ \\
\hline T7 & Total substitution with commercial salt replacer mixture & $100 \% \mathrm{Vital} \mathrm{Salt}{ }^{\mathrm{TM}}$ & $50 \%$ \\
\hline
\end{tabular}


the optimal pH (4.6) was achieved. After separating the whey, the cream cheese was mixed with selected salt combination (Control, T1, T2, T3). Table 1 shows salt composition and the codes for the samples further used in the analyses. The homogenized and hot product was filled into plastic containers ( $1 \mathrm{~kg}$ portions) and hermetically sealed. The cheeses were prepared in triplicate for each salting treatment and stored at $4{ }^{\circ} \mathrm{C}$. All analyses were performed 1 day after production. Prior to analysis, samples were kept at ambient temperature for $1 \mathrm{~h}$.

\section{Physicochemical analysis}

The $\mathrm{pH}$ values of samples were determinate using a pH meter, Model 3210 (WTW GmbH, Austria), and a pH combination electrode (BlueLine $21 \mathrm{pH}$, Schott AG, Germany). Titrable acidity was estimate by titration Method No. 920.124 (AOAC, 1990). Acidity was calculated by using the following expression:

$$
\% L A=\frac{0.0090 \cdot V_{\mathrm{NaOH}}}{\mathrm{m}_{\text {sample }}} \cdot 100
$$

Water activity $\left(a_{w}\right)$ was determined using a HygroLab 3 Set (Rotronic AG, Bassersdorf, Switzerland) at constant temperature $25^{\circ} \mathrm{C}$. Moisture (AOAC 926.08), total protein (AOAC 920.123), and fat (AOAC 933.05) contents were determined by official methods (AOAC, 1995). Sodium, potassium, magnesium, and calcium contents were measured by atomic absorption of the dry ashed cheese samples using a spectrometer PerkinElmer Analyst 100 (PerkinElmer Inc., USA), using an IDF method 119:2007 (ISO/IDF, 2007). All measurements were done in triplicate $(n=3)$ and the results are expressed as the mean value $\pm \mathrm{SD}$.

\section{Spreadability test - Texture analysis}

A single penetration test was performed to determine texture characteristics of cream cheese, using a Texture Analyser TA-XT Plus (Stable Micro Systems, UK). The instrument was equipped with a 5-kg load cell and TTC Spreadability Rig (HDP/ $\mathrm{SR}$ ), which comprises of a male $90^{\circ}$ cone probe and precisely matched female perspex cone shaped product holders. After calibration, the cream cheese sample was placed into the female cone, and the male cone penetrated into sample. The textural data (force vs. time) were registered using a program Cheese spreadability and were subsequently analysed by the instrument software (TEE 32). Spreadability parameters (firmness, work of shear, stickiness, and work of adhesion) were calculated. All measurements were performed for 5 times $(n=5)$ and results are expressed as the mean value \pm SD.

\section{Colour measurement}

MiniScan XE colorimeter (Hunter Lab, USA) was used for measuring $L^{*}, a^{*}$ and $b^{*}$ values using CIELab colour space (CIE, 1976). The $L^{*}$ value is and indicator of luminescence - the degree of lightness from black $(L=0)$ to white $(L=100)$; $a^{*}$ value represents colour ranging from red $(+)$ to green $(-)$, and $b^{*}$ value represents colour ranging from yellow $(+)$ to blue (-). The total colour difference $(\Delta \mathrm{E})$ caused by sodium reduction treatment was calculated according to equation:

$$
\Delta \mathrm{E}=\sqrt{\left(\mathrm{L}_{0}{ }^{*}-\mathrm{L}^{*}\right)^{2}+\left(\mathrm{a}_{0}{ }^{*}-\mathrm{a}^{*}\right)^{2}+\left(\mathrm{b}_{0}^{*}-\mathrm{b}^{*}\right)^{2}}
$$

where $L_{0}{ }^{*}, a_{0}{ }^{*}$ and $b_{0}^{*}$ correspond to control cheeses, and $L^{*}, a^{*}$ and $b^{*}$ to low-sodium cheeses. Before the measurement, colorimeter was calibrated with a standard black and white according to the manufacturer's instructions. The glass petri dish with cream cheese sample was placed directly on the colorimeter sensor. Colour measurements were done for 10 times $(n=10)$ and results are expressed as the mean value \pm SD.

\section{Consumer preference testing}

One hundred and thirteen (113) habitual cream cheese consumers 20 to 63 years old 87 women and 26 men) participated in this study. Three criteria were used for the selection of consumers: having a preference for cream cheese, cream cheese consumation at least once a week, and having interest in participating in the study. According to the international practice, the samples were labelled using 3-digit random numbers and presented in 
TABLE 2. Total quality scores obtained by scoring method and differences between control and reduced-sodium cream cheese as perceived by triangle test

\begin{tabular}{l|r|r|r|r}
\cline { 2 - 5 } & \multicolumn{2}{|l|}{ Sensory evaluation by scoring method } & \multicolumn{2}{l}{ Triangle test } \\
\hline Code & Total scores* $^{* * *}$ & Quality categories & Answers (correct/total) & Significant difference \\
\hline Control & $18.4 \pm 1.4^{\mathrm{a}}$ & Excellent & - & - \\
\hline T0 & $18.0 \pm 1.8^{\mathrm{a}}$ & Excellent & $7 / 36$ & $\mathrm{~ns}$ \\
\hline T1 & $15.2 \pm 1.0^{\mathrm{b}}$ & Good & $19 / 36$ & $\mathrm{P}<0.05$ \\
\hline T2 & $16.8 \pm 0.5^{\mathrm{ab}}$ & Good & $21 / 36$ & $\mathrm{P}<0.05$ \\
\hline T3 & $17.7 \pm 0.5^{\mathrm{a}}$ & Excellent & $18 / 36$ & $\mathrm{P}<0.05$ \\
\hline T4 & $13.1 \pm 1.8^{\mathrm{c}}$ & Still acceptable & $27 / 36$ & $\mathrm{P}<0.001$ \\
\hline T5 & $12.1 \pm 1.2^{\mathrm{c}}$ & Still acceptable & $28 / 36$ & $\mathrm{P}<0.001$ \\
\hline T6 & $11.5 \pm 0.6^{\mathrm{c}}$ & Still acceptable & $25 / 36$ & $\mathrm{P}<0.001$ \\
\hline T7 & $11.8 \pm 1.4^{c}$ & Still acceptable & $24 / 36$ & $\mathrm{P}<0.001$ \\
\hline
\end{tabular}

*Values (means $\pm S D ; n=7$ ) in the same column with different superscripts are significantly different by LSD test $(P<0.05)$. **Samples were classified in quality categories according to Filajdić et al., 1988. ${ }^{* * *}$ All low-sodium cream cheese (T0-T7) were presented against control cheese $(n=36)$. ${ }^{* * *}$ Significance of triangle tests was determined using the expanded statistical tables of (Roessler, Pangborn, Sidel and Stone, 1978). ns - not significant. Cheese codes are described in Table 1.

transparent plastic glasses as cream cheese. Between the evaluations, assessors used a noncarbonated mineral water.

9-point hedonic scale was used as for the acceptance testing: 1 = dislike extremely, 2 = dislike very much, 3 = dislike moderately, 4 = dislike slightly, 5 = neither like nor dislike, 6 = like slightly, 7 = like moderately, 8 = like very much, and 9 = like extremely. Liking of flavour and spreadability of the cream cheese were tested on a 5-point hedonic scale, such as follows: 1 = dislike very much, 2 = dislike slightly, 3 = neither like nor dislike, 4 = like slightly, 5 = like very much.

Just-about-right (JAR) tests were used to measure the intensity of sensory attributes that can affect the acceptance of the overall product. For JAR, consumers rated the same samples on a 5-point category scale with five descriptive anchors: much to weak, too weak, ideal/just about right, too strong, much too strong (Gacula et al., 2007). The measured attributes were saltiness (taste of salt), sourness (fresh sourness, reminding of yoghurt), bitterness (taste of bitter), overall taste (general taste of the cream cheese), fat-creamy (creamy feeling of fullness in the mouth) and spreadability (ease of spreading) of cream cheese.

\section{Statistical analysis}

The obtained experimental data were analysed by an analysis of variance (ANOVA) and Fisher's least significant difference (LSD), with significance at $P<0.05$. A statistical analysis was carried out with Statistica ver. 12.0 software (StatSoft Inc. Tulsa, USA). Penalty analysis was performed on overall liking scores based on JAR question responses. Penalty (mean-drop) analysis on overall liking and JAR scores was conducted to identify which product attributes impacted overall liking scores negatively. Data analysis for penalty analysis includes the following: The 5-point JAR scale was reduced to 3 categories, two not-JAR categories (too low, TL and too much, TM), and JAR category. For each of the selected attributes, mean drops in liking were calculated by subtracting the mean overall liking score for the JAR category to the mean overall liking score of the non-JAR category. Penalty analysis were represented graphically for individual sample using a scatter plot of the percentage of respondent in a non-JAR category on the $x$-axis and the mean drops on $y$-axis (JeanFrançois Meullenet et al., 2007). 


\section{Results and discussion}

\section{Results of preliminary study}

According to the results of sensory evaluation (Table 2), besides the control sample, the samples $\mathrm{TO}, \mathrm{T} 1, \mathrm{~T} 2$, and $\mathrm{T} 3$ belong to the excellent and good quality category, while the others, although in category "still acceptable", have large variations in their characteristic properties.

The results of the triangle test (Table 2) show that only cheese sample with $25 \%$ less sodium chloride added (TO) was indistinguishable from control cheeses. Panellists were able to distinguish samples with sodium reduced/substituted to $65 \%(\mathrm{P}<0.05)$ and $50 \%(P<0.001)$ of standard sodium level.

Although most low-sodium cheeses are different from standard cheeses, samples made with $35 \%$ sodium reduction had comparable appearance, colour, taste, aroma and consistency scores with full-sodium control cheese and were selected for further research. Sample TO omitted as preliminary results indicated that it was possible to reduce salt by more than $25 \%$.

\section{Cream cheese composition}

No significant difference $(P>0.05)$ were observed in the gross composition of cream cheese based on the salt treatment applied (data not shown). Fat, protein and moisture contents were approximately $25 \%, 7.5 \%$ and $63 \%$, respectively. Differences in salt treatments didn't influence on water activity $\left(\mathrm{a}_{\mathrm{w}}\right), \mathrm{pH}$ value and titrable acidity of cream cheese. A reduction in cheese salt content usually causes an increase in moisture and water activity and decrease of $\mathrm{pH}$, due to increase of microbial activity and protein degradation in most of cheese types (Guinee and O'Kennedy, 2007; Sihufe et al., 2018). However, when the measurements were taken a few days after cheese processing, the influence of salt reduction on metabolic activity was minimal (Carmi and Benjamin, 2017; Gomes et al., 2011). These results are consistent with those observed by Damiano and Joyner (2018b, 2018a), who studied cottage cheese.

Table 3 shows the sodium, potassium, calcium and magnesium contents in cream cheese samples. The mineral composition of cream cheese was correlated with composition of added salt mixture. No significant difference $(P>0.05)$ in calcium content was observed among all cheese samples. All treatments (T1, T2, T3) have significantly reduced the sodium content by more than $35 \%$. Increase in e potassium content from $140.40 \mathrm{mg} 100$

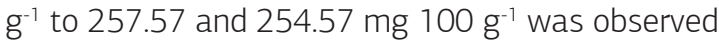
in T2 and T3 samples, representing an increase of more than $80 \%$ in the potassium concentration of the low-sodium cream cheese. As was expected, by replacing sodium with potassium, both the gravimetric and the molar ratios of $\mathrm{K}: \mathrm{Na}$ increased significantly $(\mathrm{P}<0.05)$. As it could be observed from Table 3, the use of salt replacer in T2 and T3 samples efficiently increased the molar $\mathrm{K}: \mathrm{Na}$ ratio of cream cheese to about 1.2; a value that corresponds to current nutritive recommendations for potassium and sodium molar ratios of 1.2 or 1.8 (Weaver, 2013).

TABLE 3. Mineral composition of cream cheese samples

\begin{tabular}{l|r|r|r|r|r|r}
\hline $\begin{array}{l}\text { Cheese } \\
\text { code }\end{array}$ & $\mathrm{Na}(\mathrm{mg} / 100 \mathrm{~g})$ & $\mathrm{K}(\mathrm{mg} / 100 \mathrm{~g})$ & $\mathrm{Ca}(\mathrm{mg} / 100 \mathrm{~g})$ & $\mathrm{Mg}(\mathrm{mg} / 100 \mathrm{~g})$ & $\begin{array}{r}\text { K:Na ratio } \\
\text { (gravimetric }^{\text {basis) }}\end{array}$ & $\begin{array}{r}\mathrm{K}: \mathrm{Na} \mathrm{ratio} \\
\text { (molar) }^{*}\end{array}$ \\
\hline Control & $328.17 \pm 1.04^{\mathrm{a}}$ & $140.40 \pm 0.96^{\mathrm{b}}$ & $165.47 \pm 4.08^{\mathrm{a}}$ & $20.08 \pm 0.38^{\mathrm{b}}$ & $0.252 \pm 0.001^{\mathrm{c}}$ & $0.428 \pm 0.002^{\mathrm{c}}$ \\
\hline $\mathrm{T} 1$ & $207.10 \pm 1.91^{\mathrm{b}}$ & $141.87 \pm 0.96^{\mathrm{b}}$ & $165.50 \pm 3.72^{\mathrm{a}}$ & $19.78 \pm 0.23^{\mathrm{b}}$ & $0.403 \pm 0.005^{\mathrm{b}}$ & $0.685 \pm 0.008^{\mathrm{b}}$ \\
\hline $\mathrm{T} 2$ & $208.67 \pm 7.09^{\mathrm{b}}$ & $257.57 \pm 4.83^{\mathrm{a}}$ & $168.53 \pm 4.45^{\mathrm{a}}$ & $20.20 \pm 0.19^{\mathrm{b}}$ & $0.727 \pm 0.030^{\mathrm{a}}$ & $1.235 \pm 0.051^{\mathrm{a}}$ \\
\hline $\mathrm{T3}$ & $211.23 \pm 1.66^{\mathrm{b}}$ & $254.43 \pm 2.50^{\mathrm{a}}$ & $161.33 \pm 4.93^{\mathrm{a}}$ & $24.06 \pm 0.16^{\mathrm{a}}$ & $0.709 \pm 0.011^{\mathrm{a}}$ & $1.205 \pm 0.018^{\mathrm{a}}$ \\
\hline
\end{tabular}

Values with different lower-case superscript letters within a column differ significantly $(P<0.05)$. Errors are standard deviations $(\mathrm{n}=$ 3). *Values calculated based on the molecular weight of $\mathrm{K}$ and $\mathrm{Na}$. Control - standard salt content, T1 - reduced salt content, $\mathrm{T} 2$ reduced salt content $+\mathrm{KCl}, \mathrm{T3}$ - reduced salt content $+\mathrm{KCl}+\mathrm{KMg}$-citrate. 
TABLE 4. Colour properties of cream cheese samples

\begin{tabular}{l|r|r|r|r}
\hline Cheese code & $L^{*}$ & $a^{*}$ & $b^{*}$ & $\Delta \mathrm{E}$ \\
\hline Control & $97.12 \pm 0.08^{\mathrm{a}}$ & $-0.354 \pm 0.156^{\mathrm{a}}$ & $10.48 \pm 0.09^{\mathrm{ab}}$ & - \\
\hline T1 & $97.08 \pm 0.06^{\mathrm{a}}$ & $-0.438 \pm 0.079^{\mathrm{a}}$ & $10.63 \pm 0.21^{\mathrm{ab}}$ & $0.208 \pm 0.164^{\mathrm{a}}$ \\
\hline T2 & $97.10 \pm 0.06^{\mathrm{a}}$ & $-0.422 \pm 0.101^{\mathrm{a}}$ & $10.45 \pm 0.13^{\mathrm{b}}$ & $0.261 \pm 0.124^{\mathrm{a}}$ \\
\hline T3 & $97.11 \pm 0.07^{\mathrm{a}}$ & $-0.392 \pm 0.075^{\mathrm{a}}$ & $10.66 \pm 0.06^{\mathrm{a}}$ & $0.239 \pm 0.105^{\mathrm{a}}$ \\
\hline
\end{tabular}

Values are means $\pm S D(n=10)$; values in the same column with different superscripts are significantly different $(P<0.05)$. Control standard salt content, $\mathrm{T} 1$ - reduced salt content, $\mathrm{T} 2$ - reduced salt content $+\mathrm{KCl}$, $\mathrm{T} 3$ - reduced salt content $+\mathrm{KCl}+\mathrm{KMg}$-citrate.

TABLE 5. Textural properties of cream cheese samples

\begin{tabular}{l|r|r|r|r}
\hline Cheese code & Firmness $(\mathrm{g})$ & Work of Shear $(\mathrm{g} \cdot \mathrm{s})$ & Stickiness $(\mathrm{g})$ & Work of Adhesion (g.s) \\
\hline Control & $1522.42 \pm 164.48^{\mathrm{b}}$ & $1535.92 \pm 170.57^{\mathrm{b}}$ & $-1136.44 \pm 156.03^{\mathrm{b}}$ & $-127.31 \pm 22.21^{\mathrm{a}}$ \\
\hline T1 & $1905.88 \pm 249.04^{\mathrm{a}}$ & $1811.98 \pm 240.06^{\mathrm{a}}$ & $-1403.60 \pm 207.09^{\mathrm{c}}$ & $-110.74 \pm 7.13^{\mathrm{a}}$ \\
\hline T2 & $1135.89 \pm 257.08^{\mathrm{c}}$ & $1116.83 \pm 238.12^{c}$ & $-781.90 \pm 195.23^{\mathrm{a}}$ & $-126.41 \pm 24.59^{\mathrm{a}}$ \\
\hline T3 & $1147.45 \pm 82.00^{c}$ & $1119.14 \pm 67.90^{c}$ & $-751.65 \pm 72.88^{\mathrm{a}}$ & $-128.76 \pm 29.77^{\mathrm{a}}$ \\
\hline
\end{tabular}

Values are means $\pm S D(n=5)$; values in the same column with different superscripts are significantly different $(P<0.05)$. Control standard salt content, $\mathrm{T} 1$ - reduced salt content, $\mathrm{T} 2$ - reduced salt content $+\mathrm{KCl}, \mathrm{T} 3$ - reduced salt content $+\mathrm{KCl}+\mathrm{KMg}-\mathrm{citrate}$.

\section{Spreadability of cream cheese}

Cream cheese is a soft, creamy cheese spread and consumer acceptability of such food greatly depends on its textural characteristics. Spreadability is one of the most important textural properties of cream cheese (Breidinger and Steffe, 2001). Spreadability describes a measure of how easily and uniformly spread can be deformed and distributed over the surface in a layer. Table 5 shows textural attributes of control and reduced sodium cream cheeses. Reduction in sodium content of cream cheese had a significant effect $(P<0.05)$ on instrumental measured firmness, work of shear, and stickiness but did not show a significant effect $(P>0.05)$ on of adhesion compared with the control sample.

Simple salt reduction in $T 1$ sample increased firmness, work of shear, and stickiness. This indicates a lower spreadability of the sample with reduced salt content. Many studies on other types of cheese (Akkerman et al., 2017; McCarthy et al., 2016; Sheibani et al., 2015; Sihufe et al., 2018) have shown the opposite trend when the reduction in the salt content caused a decrease in cheese hardness. However, all of the mentioned researches were performed on cheeses obtained by rennet coagulation, while cream cheese is a fresh cheese obtained by lactic acid fermentation. Damiano and Joyner (2018b) and Köksoy and Kiliç (2003) investigated the effect of sodium chloride content on the properties of fermented milk systems. They found that reduction of the sodium chloride content causes increase in the viscosity of the acidic milk gel and other acidic dairy products. Results of this study correlate with the result obtained in this study. It could be explained by the repulsive forces of the sodium ions on the surface of the casein micelles, which reduces the aggregation of the casein micelles and thus causes a lower firmness and other textural properties of salted cream cheese (Schkoda et al., 1999).

Conversely, a partial replacement of sodium chloride with potassium chloride (T2, T3) had the opposite effect on hardness, and other textural attributes in comparison with simple salt reduction. Numerous studies on the use of potassium salts in cheeses have shown different effects on textural properties, depending on the type of cheese. The results of certain studies show that salt replacement increases the hardness of cheese (Gomes et al., 2011; Soares et al., 2016). The results of some studies indicated that $\mathrm{KCl}$ had a decreasing effect (Carmi and Benjamin, 2017), but the re- 
sults of certain studies showed that substitution had no effect on textural properties (Costa et al., 2018; Costa et al., 2019; Grummer et al., 2012; Katsiari et al., 1997, 1998; Thibaudeau et al., 2015). Furthermore, some studies indicated that the hardness of Ksubstituted cheese changes during ripening (Akan, 2018). In our experiment, the replacement of sodium by potassium salts lead to a decrease in textural properties. In fresh acid cream cheese, the decrease in hardness could be explained by the Hofmeister effect, according to which $\mathrm{K}+$ decreases ionic strength more than $\mathrm{Na}+$ (Carr et al., 2002).

\section{Colour of cream cheese}

Cream cheese is characterized by a slightly yellowish white colour (USDA, 1997). Results of the colour determination, Hunter colour $L^{*}, a^{*}, b^{*}$ values and total colours difference $(\Delta \mathrm{E})$ shows Table 4. The $L$ * values (lightness) of the samples were about 97, indicating the high whiteness of this highly homogenized product. The values of $a^{*}$ (- greenness, + redness) ranged from -0.354 to 0.438 , and $b^{*}$ values (-blueness, + yellowness) ranged from 10.45 to 10.66 , which is within the range for this product type.

Although Wendin et al. (2000) reported that the salt content had a significant effect on the cream cheese yellow colour, this was not confirmed in this study. Salt reduction, as well as salt substitution, did not influence significantly $(P>0.05)$ on the $L^{*}, a^{*}$ and $b^{*}$ value of cream cheese colour. Only a difference in $b^{*}$ value was observed between the sample in which sodium chloride was partially replaced by potassium chloride and the sample with the salt mixture. The total colour difference $(\Delta \mathrm{E})$ between control and low-sodium cream cheeses, whose values ranged from 0.208 to 0.239 were not observed by trained sensory panellists. This is consistent with the claims of Mokrzycki and Tatol (2011) that only experienced observers could notice a total colour difference at a value greater than 1 .

\section{Sensory properties of cream cheese}

\section{Hedonic ratings}

Fig. 1 shows the results of evaluation of consumers average liking presented by hedonic scale. All salt reduction treatments have received lower scores of overall acceptability, taste and spreadability scores compared to standard salting.

The reduction in sodium content ( $\mathrm{T} 1)$ as well as partial substitution by potassium (T2) significantly negatively affected the cream cheese taste liking $(P<0.05)$. Consumers commented that the $T 1$ treatment (35\% less than the standard sodium sample) was bland or unsalted. $31 \%$ of panellists evaluated T1 sample as too acidic. Potassium chloride contribute to bitter, metallic and side flavour in foods (Cepanec et al., 2017b). Although in treatment T2 only a partial replacement of sodium chloride by potassium chloride was carried out, many consumers perceived bitterness, offflavour and too strong overall taste (52\%, $47 \%$ and $24 \%$ respectively).

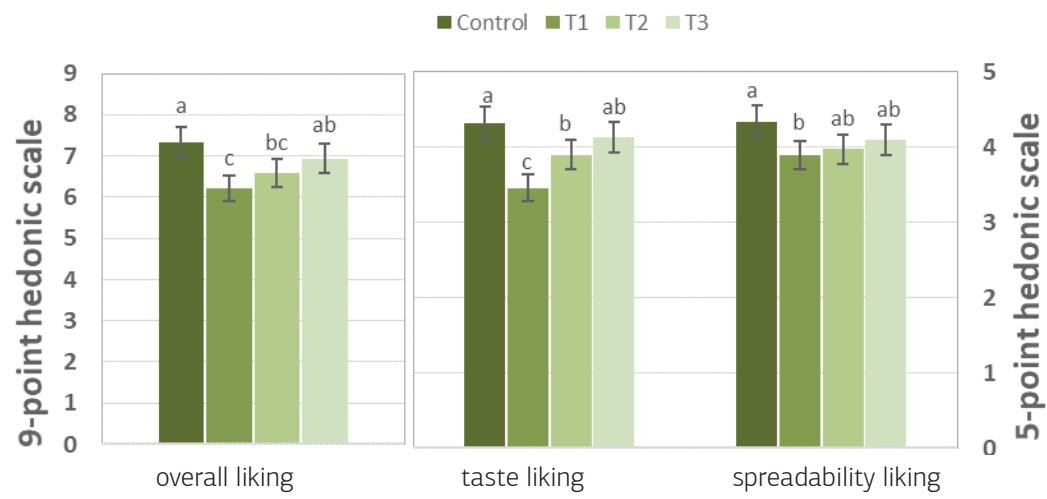

FIGURE 1. Hedonic ratings of overall acceptance, taste and spreadability acceptance for cream cheese samples

Overal liking evaluated using a 9-point hedonic scale, where $9=$ like extremely, $5=$ neither like nor dislike, and $1=$ dislike extremely, and taste and spreadability liking evaluated using a 5-point hedonic scale, where 5 = like very much, 3 = neither like nor dislike, and 1 $=$ dislike very much. Values are means $\pm \mathrm{SD}(\mathrm{n}=113)$; values in the same column with different superscripts are significantly different $(\mathrm{P}<0.05)$. Control - standard salt content, $\mathrm{T} 1$ - reduced salt content, $\mathrm{T} 2$ - reduced salt content $+\mathrm{KCl}$, $\mathrm{T} 3$ - reduced salt content $+\mathrm{KCl}+$ KMg-citrate 
In the sample with completely replaced salt by the commercial salt mixture, which also contains potassium chloride as a base (T3), sodium reduction had no significant negative effect on the taste liking score $(P>0.05)$. T3 samples were evaluated by lower mean scores for taste (4.1) compared to the control sample (4.3), but $29 \%$ of consumers commented that it tasted better than standard samples. Although this blend is based on replacement by $\mathrm{KCl}$, there were no negative comments about bitterness and off-tastes. This is probably due to the presence of substances that mask bitterness and off-flavours of potassium chloride and enhance saltiness intensity (Cepanec et al., 2017a).

The results of evaluation of spreadability liking indicated that the low-sodium cream cheese substituted with $\mathrm{KCl}$ or $\mathrm{KCl}$-based salt mixture achieved spreadability liking scores similar to that of full-sodium cream cheese. In contrast to that, the low-sodium cream cheese with a simple $\mathrm{NaCl}$ reduction resulted in significantly lower spreadability rating. Panellists indicated that the product was too hard to spread. This was correlated with the instrumentally-measured texture of cream cheese, where the $T 1$ sample had the highest values for firmness, work of shear and work of adhesion (Table 5).

Overall liking scores of the $\mathrm{T} 1$ treatment were significantly lower than those of the full-sodium cheese. Other saltreduction treatments showed comparable acceptance as standard-salted cream cheese.

Differences in flavour rating between $\mathrm{T} 2$ samples and control samples did not significantly affect the overall acceptability. This led us to hypothesize that spreadability, rather than flavour, had a more significant impact on overall liking. Wendin et al. (2000) reported that the texture attributes are more important than taste and flavour attributes for cheese acceptability.

\section{Just-about-right (JAR) scaling}

Table 6 shows scores obtained by JAR test for the intensity of specific attributes of the cream cheeses. Saltiness, bitterness, the overall flavour and spreadability of the cheeses were significantly different among various cheeses $(P<0.05)$. Only the intensity of creamy feeling in the mouth is similar in all samples and very close to just-aboutright level.

In JAR test, bitterness intensity of cheese with partial substitution by $\mathrm{KCl}$ (T2) were significantly higher $(P<0.05)$ than those for control and other low-sodium cheese samples. These responses were expected since potassium chloride is characterised by a bitter, chemical and metallic side tastes ( $\mathrm{Si}$ nopoli and Lawless, 2012). These results are in correlation with the acceptance rating test where multiple consumers detected bitterness and unusual taste of the T2 sample. Cream cheese with simple salt reduction ( $\mathrm{T} 1$ ) was significantly more souracidic, harder and less spreadable, less salty and less strength of overall taste $(P<0.05)$ when compared with those with standard salt content. No significant differences ( $P>0.05$ ) between sample T3 and control cream cheese were observed for sourness, bitterness, overall taste, spreadability and fat-creamy.

In general, only control and T3 cream cheese treatment were reported to have just-right inten-

TABLE 6. Just-about-right (JAR) responses* for intensity of sensory attributes of cream cheese samples

\begin{tabular}{r|r|r|r|r|r|r}
\hline Cheese code & Saltiness & Sourness & Bitterness & Overall taste & Spreadability & Fat-creamy \\
\hline Control & $0.28 \pm 0.65^{\mathrm{a}}$ & $0.01 \pm 0.46^{\mathrm{b}}$ & $0.07 \pm 0.35^{\mathrm{b}}$ & $0.03 \pm 0.56^{\mathrm{a}}$ & $-0.25 \pm 0.73^{\mathrm{b}}$ & $0,08 \pm 0,60^{\mathrm{a}}$ \\
\hline$T 1$ & $-0.67 \pm 0.74^{\mathrm{c}}$ & $0.42 \pm 0.73^{\mathrm{a}}$ & $0.06 \pm 0.81^{\mathrm{b}}$ & $-0.64 \pm 0.68^{\mathrm{b}}$ & $-0.63 \pm 0.87^{\mathrm{a}}$ & $0,28 \pm 0,72^{\mathrm{a}}$ \\
\hline$T 2$ & $0.04 \pm 0.78^{\mathrm{a}}$ & $0.08 \pm 0.73^{\mathrm{b}}$ & $0.78 \pm 0.83^{\mathrm{a}}$ & $0.17 \pm 0.10^{\mathrm{a}}$ & $-0.27 \pm 0.66^{\mathrm{b}}$ & $0,11 \pm 0,88^{\mathrm{a}}$ \\
\hline$T 3$ & $-0.10 \pm 0.72^{\mathrm{b}}$ & $0.06 \pm 0.53^{\mathrm{b}}$ & $0.19 \pm 0.40^{\mathrm{b}}$ & $-0.06 \pm 0.67^{\mathrm{a}}$ & $-0.24 \pm 0.73^{\mathrm{b}}$ & $0,11 \pm 0,66^{\mathrm{a}}$ \\
\hline
\end{tabular}

*Evaluated using a 5-point JAR scale $(-2=$ much to weak, $-1=$ too weak , $0=J A R,+1=$ too strong,$+2=$ much too strong). Values are means \pm SD $(n=113)$; values in the same column with different superscripts are significantly different $(P<0.05)$. Control - standard salt content, T1 - reduced salt content, $\mathrm{T} 2$ - reduced salt content $+\mathrm{KCl}, \mathrm{T} 3$ - reduced salt content $+\mathrm{KCl}+\mathrm{KMg}$-citrate. 
sity of all measured attributes (more than $56 \%$ of consumers selected the just-right category for saltiness, bitterness, sourness, overall taste, spreadability and fat-creamy (Fig. 2). Salt-reduction treatment $\mathrm{T} 1$ was reported as not salty enough and not overall tasty enough by over $50 \%$ of the population
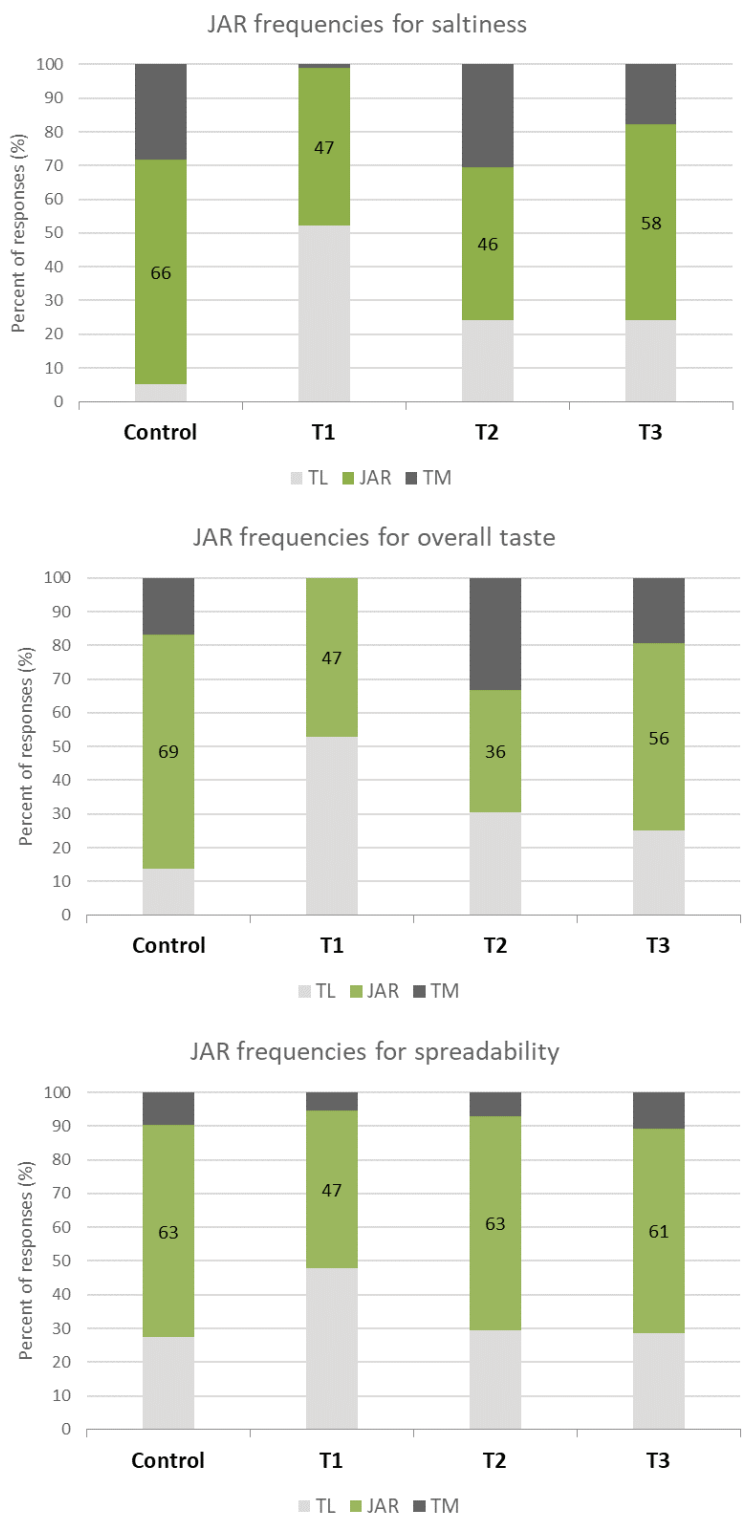

(52\% and $53 \%$, respectively). More than $50 \%$ of the consumers indicated that the bitterness of the sample T2 was too much, while over $25 \%$ panellists evaluated the spreadability of all cream cheeses as too hard.
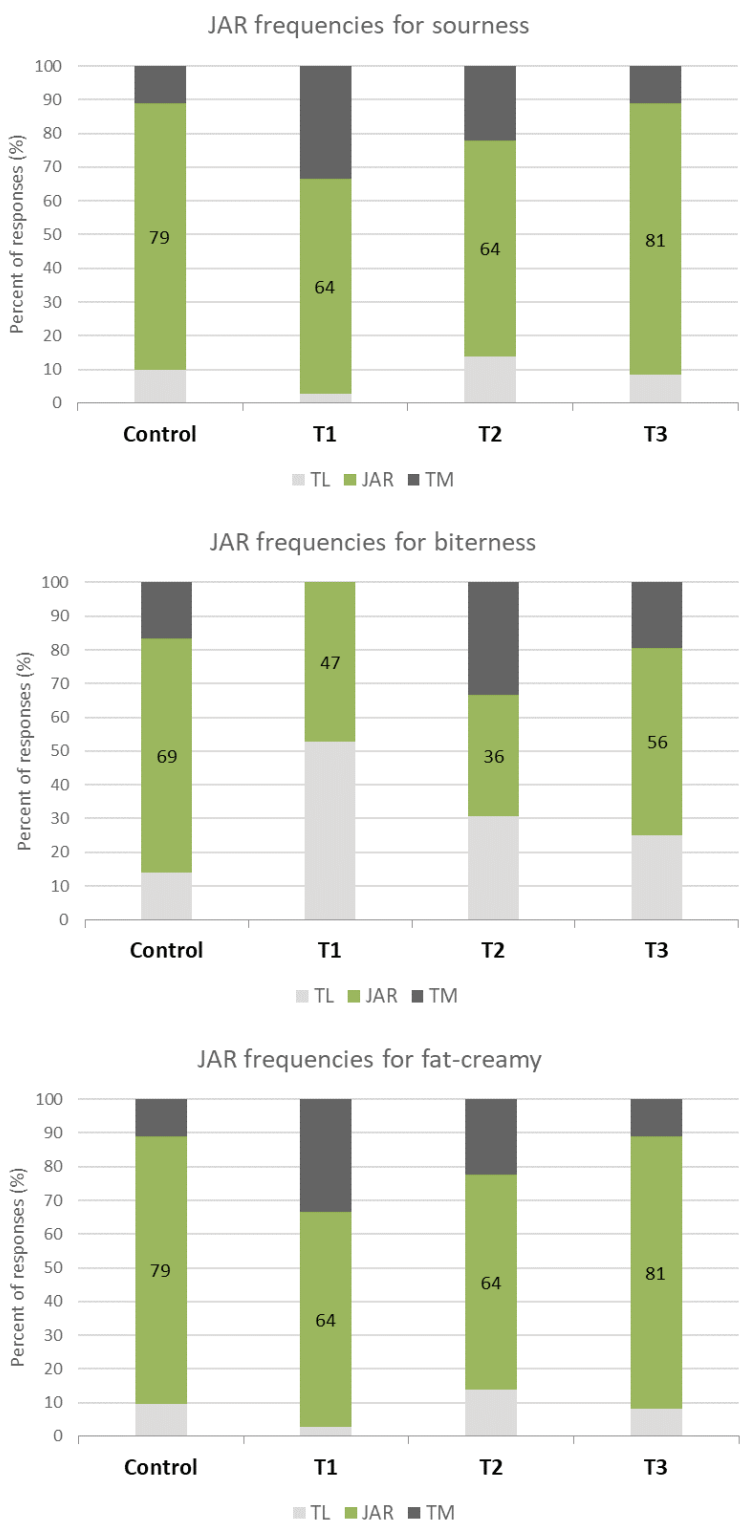

TL - too little, JAR - justabout-right, TM - too much. Control - standard salt content, T1 - reduced salt content, T2 - reduced salt content $+\mathrm{KCl}, \mathrm{T} 3$ - reduced salt content $+\mathrm{KCl}+\mathrm{KMg}$-citrate

FIGURE 2. JAR scale percentage of respondents grouped in three levels 

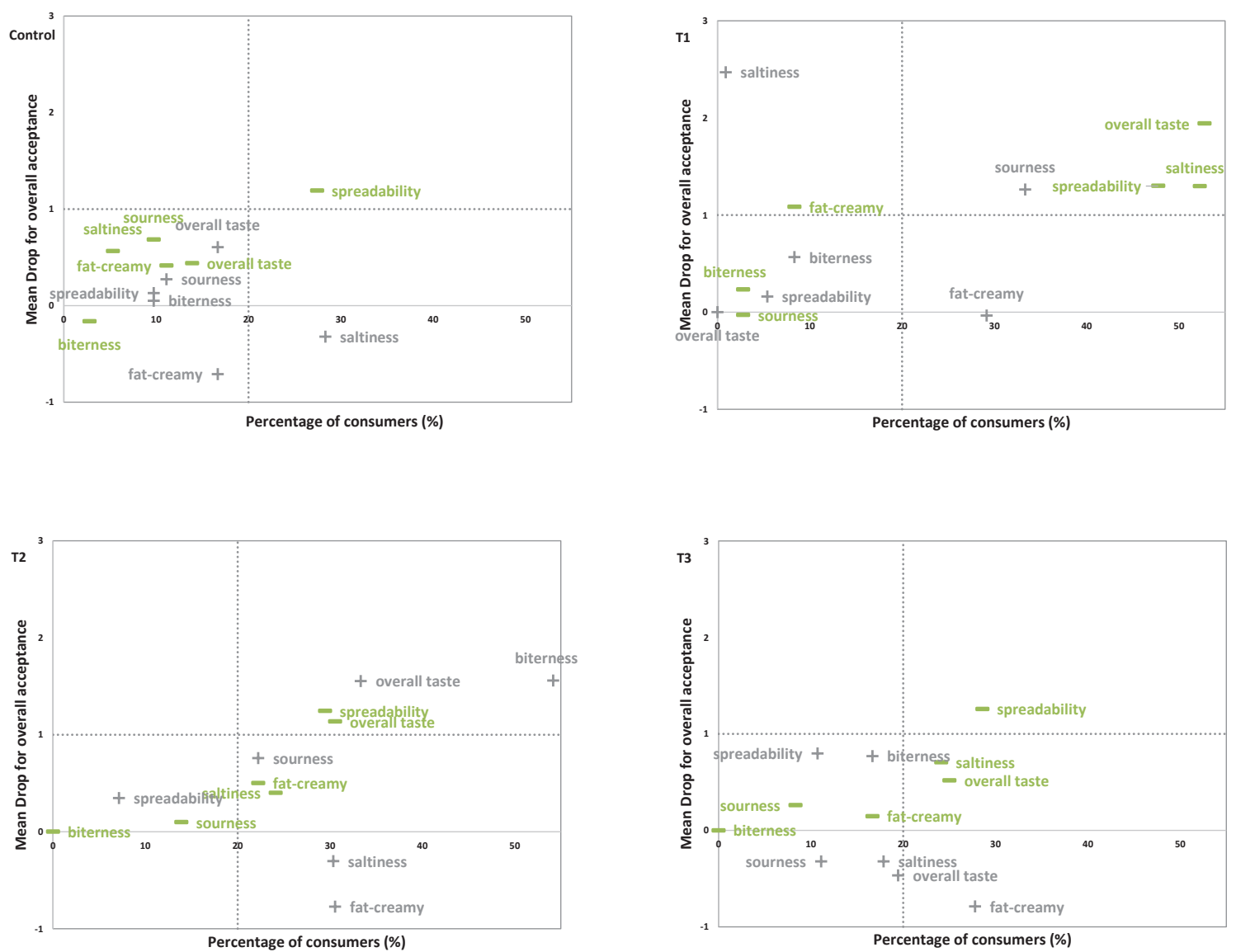

The too low intensity of attributes are highlight with green (-), and too strong with grey (+). The vertical dashed line represents the $20 \%$ of consumers, and the horizontal dashed line the decrease of 1 point in acceptance. Control - standard salt content, T1 reduced salt content, $\mathrm{T} 2$ - reduced salt content $+\mathrm{KCl}, \mathrm{T3}$ - reduced salt content $+\mathrm{KCl}+\mathrm{KMg}$-citrate.

FIGURE 3. Penalty analysis plot for cream cheese samples

Penalty analysis

Penalty analysis data are summarized in Fig. 3. The attributes contained in the upper right quadrant of penalty plot represented a greater impact on the mean drop in acceptance, when at least $20 \%$ of panellist stated that they were too much or too weak, decreasing more than 1 point on 9-point hedonic scales (Jean-François Meullenet et al., 2007).

Results of penalty analysis (Fig. 3a) show that solely low spreadability decreased the acceptance of control cheese sample. It could be concluded that those consumers who rated spreadability as poor, also gave lower scores for overall acceptance. Almost $30 \%$ of consumers have perceived all samples of cream cheese as low spreadable (Fig. 2).
The overall taste and saltiness of cream cheese with reduced salt ( $\mathrm{T} 1)$ were found to be too weak by over of $50 \%$ of the respondents and was responsible for a large drop in hedonic scores (Fig. 3b; almost 2 point and 1.5 on the 9-point hedonic scale, respectively). The spreadability was found to be too low and sourness too strong by more than $30 \%$ of the consumers (48\% and $33 \%$, respectively), and had a penalty more than 1 point.

Fig. $3 c$ shows that the cream cheese sample T2 was far from optimised from the sensory standpoint. Too strong bitterness was noticed by more than $50 \%$ of tested consumers and decreased the acceptance by about 1.5 point. This sample is interesting, as a large number of panellists (more than $30 \%$ ) have characterized T2 salt-reduction 
treatment as too high or as too weak overall taste. This could be explained by bipolarity of consumers. Data from consumer testing showed that respondents who commented sample $\mathrm{T} 2$ as not enough salty were rated its overall flavour as not enough, while those respondents who commented its taste as bitter, unpleasant, strange, tangy were evaluated the overall taste as a too intense. Both non-optimal levels of an attribute have caused a decreasing in the rating for acceptability for more than 1 point. Also, hedonic score was penalised for more than 1 point due to low spreadability of this cream cheese sample.

In T3 sample only the lower spreadability, which was found in all samples, were significantly influenced the mean drop in hedonic score for overall acceptance (Fig. 3d). Lower saltiness observed in this sample by more than $20 \%$ respondents did not negative effect the overall liking of cream cheese.

Penalty analysis results indicated that overall liking was penalized when cream cheese was too hard to spread and when overall taste and salty taste were perceived by consumer as too low, and bitterness and sourness too high. Overall, it was found that poor spreadability of cream cheese noticed in all samples was significantly penalized acceptance of this product.

\section{Conclusions}

The partial reduction and/or substitution of sodium chloride by potassium chloride to $65 \%$ of sodium level in standard cheese did not affect the physicochemical characteristic and colour of cream cheese. Cheeses in which salt has been replaced by potassium salt mixtures, the molar $\mathrm{K}: \mathrm{Na}$ ratio increased to the nutritional recommended value. Significant effect on the textural and sensory properties of different salt treatment was observed. Although, a difference in taste liking, spreadability liking and overall liking was observed, all cream cheese samples showed good consumer acceptance. The cheese with simple salt reduction was perceived as too acidic, not salty and not tasty enough. The samples, which contained potassium chloride, perceived as bitterish. Finally, cheese with potassium salt mixture containing a bitter masking agents, among all salt reduction treatments, has been evaluated with the highest scores, without notice of the bitterness and other off-tastes. Salut ${ }^{\oplus}$ commercial salt blend has proven to be an effective salt substitute for production of lowsodium cream cheese. The spreadability of all samples was considered as too hard. Accordingly future steps in investigations could be the development of cream cheese with higher spreadability.

\section{Acknowledgements}

This research was financially supported by Podravka Ltd. Croatia. All cream cheese samples were provided with the generosity of Belje Plus Dairy (Darda, Croatia): Davor Bošnjaković, Duško Lapac, and Darija Kostelić Kuhar.

\section{Fizikalno-kemijska svojstva, mazivost i prihvatljivost krem sira sa sniženim udjelom natrija}

\section{Sažetak}

Istraživanje je provedeno kako bi se istražila mogućnost smanjenja natrija u krem siru, djelomičnom redukcijom odnosno zamjenom natrija pomoću kalijevih soli. Preliminarnim ispitivanjem odabrana su 4 načina soljenja: 100 \% NaCl (kontrola), NaCl snižen na 65 \% (T1), 35 \% NaCl-a zamijenjeno KCl-om (T2), i mješavina soli Salut ${ }^{\oplus}$ na bazi KCl-a koja sadrži i tvari za prikrivanje stranih okusa (T3). Istraživanjem su ispitivana fizikalno-kemijska svojstva, boja, mazivost, prihvatljivost, kao i stupanj intenziteta specifičnih svojstava krem sira sa sniženim udjelom natrija. Snižavanje udjela natrija nije utjecalo na udio proteina, mliječne masti i vode, aktivitet vode, kiselost i boju krem sira ( $P>0,05)$. Međutim, redukcija natrija je značajno utjecala na mineralni sastav, mazivost i senzorska svojstva. Primjena mješavina soli na bazi 


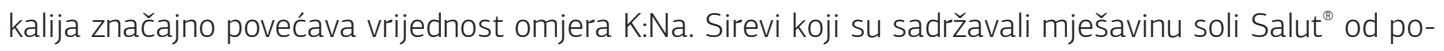
trošača su dobili ocjene najbliže kontrolnom siru, u usporedbi s ostalim zamjenama. Ovo istraživanje pokazuje da je moguće smanjenje udjela natrija u krem siru za 35 \% primjenom nutritivno vrijednih mješavina soli na bazi kalija, bez narušavanja prihvatljivosti proizvoda.

\section{Ključne riječi: krem sir, smanjenje natrija, kalijev klorid, mazivost, senzorska analiza}

\section{References}

1. Akan, E. (2018): Effect of mineral salt replacement on properties of Turkish White cheese. Mljekarstvo 68 (1), 46-56.

https://doi.org/10.15567/mljekarstvo.2018.0106

2. Akkerman, M., Kristensen, L.S., Jespersen, L., Ryssel, M.B., Mackie, A., Larsen, N.N., Andersen, U.,Nørgaard, M.K., Løkke, M.M., Møller, J.R. (2017): Interaction between sodium chloride and texture in semi-hard Danish cheese as affected by brining time, DL-starter culture, chymosin type and cheese ripening. International Dairy Journal 70, 34-45. https://doi.org/10.1016/j.idairyj.2016.10.011

3. AOAC. Acidity 920.124 (1990).

4. AOAC. Official methods of analysis (1995).

5. Ayyash, M.M., Shah, N.P. (2011): The effect of substitution of $\mathrm{NaCl}$ with $\mathrm{KCl}$ on chemical composition and functional properties of low-moisture Mozzarella cheese. Journal of Dairy Science 94(8), 3761-3768. https://doi.org/10.3168/jds.2010-4103

6. Bae, I., Park, J.-H., Choi, H.-Y., Jung, H.-K. (2017): Emerging innovations to reduce the salt content in cheese; effects of salt on flavor, texture, and shelf life of cheese; and current salt usage: A review. Korean Journal for Food Science of Animal Resources 37 (6), 793-798. https://doi.org/10.5851/kosfa.2017.37.6.793

7. Breidinger, S.L., Steffe, J.F. (2001): Texture map of cream cheese. Journal of Food Science 66 (3), 453-456. https://doi.org/10.1111/j.1365-2621.2001.tb16128.x

8. Carmi, I.K., Benjamin, O. (2017): Reduction in sodium content of fresh, semihard Tzfat cheese using salt replacer mixtures: taste, texture and shelf life evaluation. International Journal of Dairy Technology 70 (3), 354-364. https://doi.org/10.1111/1471-0307.12369

9. Carr, A.J., Munro, P.A., Campanella, O.H. (2002): Effect of added monovalent or divalent cations on the rheology of sodium caseinate solutions. International Dairy Journal 12 (6), 487-492. https://doi.org/10.1016/S0958-6946(02)00024-9

10. Cepanec, I., Ranilović, J., Cvetković, T., Vugrinec, S. (2017a): Salt substitute composition, preparation and use thereof. Croatia. PCT Patent Application No. PCT/HR2015/000016, Published as WO2017/046620A1, March 23, 2017.

11. Cepanec, K., Vugrinec, S., Cvetković, T., Ranilović, J. (2017b): Potassium Chloride-Based Salt Substitutes: A Critical Review with a Focus on the Patent Literature. Comprehensive Reviews in Food Science and Food Safety 16 (5), 881-894.

https://doi.org/10.1111/1541-4337.12291
12. CFA - Croatian Food Agency. (2014): "Less salt - more health". Osijek.

13. CIE (1976) Colorimetry: Official recommendation of the international commission on illumination publication CIE No. (E-1.31). Paris, France: Bureau Central de la CIE.

14. Costa, R.G.B., Sobral, D., Teodoro, V.A.M., Costa, L.C.G., de Paula, J.C.J., Landin, T.B., de Oliveira, M.B. (2018): Sodium substitutes in Prato cheese: Impact on the physicochemical parameters, rheology aspects and sensory acceptance. LWT - Food Science and Technology 90, 643-649. https://doi.org/10.1016/j.lwt.2017.12.051

15. Costa, G.B., Junior, A.C., da Cruz, A.G., Sobral, D., Júnior, L.C.G.,C., de Paula, J.C.J., Moreira, G.M., Teodoro, V.A.M. (2019): Effect of partial replacement of sodium chloride with potassium chloride on the characteristics of Minas Padrão cheese. International Dairy Journal 91, 48-54. https://doi.org/10.1016/j.idairyj.2018.12.002

16. Cruz, A.G., Faria, J.A.F., Pollonio, M.A.R., Bolini, H.M.A., Celeghini, R.M.S., Granato, D., Shah, N.P. (2011): Cheeses with reduced sodium content: Effects on functionality, public health benefits and sensory properties. Trends in Food Science and Technology 22 (6), 276-291. https://doi.org/10.1016/j.tifs.2011.02.003

17. Damiano, H., Joyner, H.S. (2018a): The impact of $\mathrm{NaCl}$ replacement with $\mathrm{KCl}$ and $\mathrm{CaCl}_{2}$ on cottage cheese cream dressing rheological behavior and consumer acceptance. International Dairy Journal 78, 73-84. https://doi.org/10.1016/j.idairyj.2017.10.003

18. Damiano, H., Joyner, H.S. (2018b): The impact of salt reduction on cottage cheese cream dressing rheological behavior and consumer acceptance. International Dairy Journal 79, 62-72. https://doi.org/10.1016/j.idairyj.2017.12.008

19. Dehghan, M., Mente, A., Rangarajan, S., Sheridan, P., Mohan, V., Iqbal, R., Yusuf, S. (2018): Association of dairy intake with cardiovascular disease and mortality in 21 countries from five continents (PURE): a prospective cohort study. The Lancet 392 (10161), 2288-2297. https://doi.org/10.1016/S0140-6736(18)31812-9

20. EC - European Commission (2012): EU Salt Reduction Framework. Retrieved from https://ec.europa.eu/health/ sites/health/files/nutrition_physical_activity/docs/salt_ report1_en.pdf

21. EFSA - European Food Safety Authority (2006): Tolerable upper intake levels for vitamins and minerals. Retrieved from http://www.efsa.europa.eu/sites/default/files/efsa_ rep/blobserver_assets/ndatolerableuil.pdf 
22. Filajdić, M., Ritz, M., Vojnović, V. (1988): Sensory analysis of the milk products. Mljekarstvo 38 (11), 295-301.

23. FSA - Food Standards Agency (2006): New salt reduction targets published. Retrieved from http://www.food.gov.uk/ news/newsarchive/2006/mar/salttargets

24. Gacula, M., Rutenbeck, S., Pollack, L., Resurreccion, A.V.A., Moskowitz, H.R. (2007): The just-about-right intensity scale: Functional analyses and relation to hedonics. Journal of Sensory Studies 22 (2), 194-211. https://doi.org/10.1111/j.1745-459X.2007.00102.x

25. Guinee, T.P. (2004). Salting and the Role of Salt in Cheese. International Journal of Dairy Technology, 57 (2-3).

26. Guinee, T. P., O'Kennedy, B.T. (2007): Reducing salt in cheese and dairy spreads. In: Kilcrest D, Angus F, editors. Reducing salt in foods. Cambridge, England: Woodhead Publishing Limited. https://doi.org/10.1201/9781439824511.ch16

27. Gomes, A.P., Cruz, A.G., Cadena, R.S., Celeghini, R.M.S., Faria, J.A.F., Bolini, H.M., Pollonio, M.A., Granato, D. (2011): Manufacture of low-sodium Minas fresh cheese - Effect of the partial replacement of sodium chloride with potassium chloride. Journal of Dairy Science 94 (6), 2701-2706. https://doi.org/10.3168/jds.2010-3774

28. Government of the Republic of Croatia. (2014): Strategic Plan for the Reduction of excessive salt intake in Croatia 2015-2019. Retrieved from http://www.hzjz.hr/wpcontent/uploads/2014/11/Strateški-plan-za-smanjenjeprekomjernog-unosa-kuhinjske-soli-u-RH-2015.-2019.pdf.

29. Grummer, J., Karalus, M., Zhang, K., Vickers, Z., Schoenfuss, T.C. (2012): Manufacture of reduced-sodium Cheddar-style cheese with mineral salt replacers. Journal of Dairy Science 95 (6), 2830-2839. https://doi.org/10.3168/jds.2011-4851

30. ISO/IDF (2007). Milk and milk products - Determination of calcium, sodium, potassium and magnesium contents Atomic absorption spectrometric method. ISO 8070:2007 (IDF 119:2007).

31. ISO/IDF (2009). Milk and milk products - Sensory analysis - Part 3: 22935-3:2009 Guidance on a method for evaluation of compliance with product specifications for sensory properties by scoring.

32. Meullenet, J-F., Xiong, R., Findlay, C.J. (2007): Multivariate and Probabilistic Analyses of Sensory Science Problems. IFT Press, Chicago, IL.

33. Katsiari, M.C., Alichanidis, E., Voutsinas, L.P., Roussis, I.G. (2000): Proteolysis in reduced sodium Feta cheese made by partial substitution of $\mathrm{NaCl}$ by $\mathrm{KCl}$. International Dairy Journal 10(9), 635-646. https://doi.org/10.1016/S0958-6946(00)00097-2

34. Katsiari, M.C., Voutsinas, L.P., Alichanidis, E., Roussis, I.G. (1997): Reduction of sodium content in Feta cheese by partial substitution of $\mathrm{NaCl}$ by $\mathrm{KCl}$. International Dairy Journal 7 (6-7), 465-472. https://doi.org/10.1016/S0958-6946(97)00032-0

35. Katsiari, M.C., Voutsinas, L.P., Alichanidis, E., Roussis, I.G. (1998): Manufacture of Kefalograviera cheese with less sodium by partial replacement of $\mathrm{NaCl}$ with $\mathrm{KCl}$. Food Chemistry 61 (1-2), 63-70. https://doi.org/10.1016/S0308-8146(97)00113-1
36. Khetra, Y., Kanawjia, S.K., Puri, R. (2016): Selection and optimization of salt replacer, flavour enhancer and bitter blocker for manufacturing low sodium Cheddar cheese using response surface methodology. LWT - Food Science and Technology 72, 99-106.

https://doi.org/10.1016/j.lwt.2016.04.035

37. Khetra, Y., Kanawjia, S.K., Puri, R., Kumar, R., Meena, G.S. (2019): Using taste-induced saltiness enhancement for reducing sodium in Cheddar cheese: Effect on physicochemical and sensorial attributes. International Dairy Journal 91, 165-171 https://doi.org/10.1016/j.idairyj.2018.08.003

38. Köksoy, A., Kiliç, M. (2003): Effects of water and salt level on rheological properties of ayran, a Turkish yoghurt drink. International Dairy Journal 13(10), 835-839. https://doi.org/10.1016/S0958-6946(03)00103-1

39. Lactimed (2015): The dairy products market Documentary study. Retrieved from http://www.animaweb. org/sites/default/files/document_etude_debouches_ lactimed_en_web_final.pdf

40. McCarthy, C.M., Wilkinson, M.G., Kelly, P.M., Guinee, T.P. (2016): Effect of salt and fat reduction on proteolysis, rheology and cooking properties of Cheddar cheese. International Dairy Journal 56, 74-86. https://doi.org/10.1016/j.idairyj.2016.01.001

41. Mokrzycki, W., Tatol, M. (2011): Color difference Delta E - A survey. Machine Graphics and Vision, 20 (4), 383-411.

42. Mozuraityte, R., Berget, I., Mahdalova, M., Grønsberg, A., Øye, E.R., Greiff, K. (2019): Sodium reduction in processed cheese spreads and the effect on physicochemical properties. International Dairy Journal 90, 45-55. https://doi.org/10.1016/j.idairyj.2018.10.008

43. Nogueira, E.B., Costa-Lima, B.R.C., Torres, F., Regazone, A.V., Melo, L., Franco, R.M., Cortez, M.A.S. (2018): Effect of potassium-based emulsifying salts on the sensory and physicochemical parameters of low-sodium spreadable processed cheese. International Journal of Dairy Technology 71 (3), 717-722. https://doi.org/10.1111/1471-0307.12519

44. O'Donnell, M., Mente, A., Yusuf, S. (2015): Sodium Intake and Cardiovascular Health. Circulation Research 116 (6), 1046-1057. https://doi.org/10.1161/CIRCRESAHA.116.303771

45. OECD/FAO. (2016): Dairy and Dairy Products. In OECD-FAO Agricultural Outlook 2016-2025. Paris: OECD Publishing. https://doi.org/10.1787/agr-outl-data-en

46. Phadungath, C. (2005): Cream cheese products - a review. Songklanakarin Journal of Science and Technology 27 (1), 191-199.

47. Ranilović, J., Gajari, D., Tomić-Obrdalj, H., Cvetković, T., Colić Barić, I. (2019): Salt Reduction: Translation of consumer expectations into wishful taste product attribute, International Journal of Food Engineering 5 (1), 43-49

48. Rice, B.H., Quann, E.E., Miller, G.D. (2013). Meeting and exceeding dairy recommendations: Effects of dairy consumption on nutrient intakes and risk of chronic disease. Nutrition Reviews 71 (4), 209-223. https://doi.org/10.1111/nure.12007 
49. Rodrigues, J.F., Gonçalves, C.S., Pereira, R.C., Carneiro, J.D.S., Pinheiro, A.C.M. (2014): Utilization of temporal dominance of sensations and time intensity methodology for development of low-sodium Mozzarella cheese using a mixture of salts. Journal of Dairy Science 97 (8), 4733-4744. https://doi.org/10.3168/jds.2014-7913

50. Roessler, E.B., Pangborn, R.M., Sidel, J.L., Stone, H. (1978): Expanded statistical tables for estimating significance in paired-preference, paired-difference, duo-trio and triangle tests. Journal of Food Science 43.

51. Schkoda, P., Hechler, A., Kessler, H.G. (1999): Effect of minerals and $\mathrm{pH}$ on rheological properties and syneresis of milk-based acid gels. International Dairy Journal 9 (3-6), 269-274. https://doi.org/10.1016/S0958-6946(99)00073-4

52. Sheibani, A., Ayyash, M.M., Shah, N.P., Mishra, V.K. (2015): The effects of salt reduction on characteristics of hard type cheese made using high proteolytic starter culture. International Food Research Journal 22 (6), 2452-2459.

53. Sihufe, G.A., De Piante Vicín, D.A., Marino, F., Ramos, E.L., Nieto, I.G., Karlen, J.G., Zorrilla, S.E. (2018): Effect of sodium chloride reduction on physicochemical, biochemical, rheological, structural and sensory characteristics of Tybo cheese. International Dairy Journal 82, 11-18. https://doi.org/10.1016/j.idairyj.2018.02.006

54. Sinopoli, D.A., Lawless, H.T. (2012): Taste Properties of potassium chloride alone and in mixtures with sodium chloride using a Check-All-That-Apply method. Journal of Food Science 77 (9), 1-4. https://doi.org/10.1111/j.1750-3841.2012.02862.x

55. Soares, C., Fernando, A.L., Alvarenga, N., Martins, A.P.L. (2016): Substitution of sodium chloride by potassium chloride in São João cheese of Pico Island. Dairy Science and Technology 96 (5), 637-655. https://doi.org/10.1007/s13594-016-0293-2
56. Strazzullo, P., Leclercq, C. (2014): Nutrient Information. Sodium. Advances In Nutrition 2, 188-190. https://doi.org/10.3945/an.113.005215

57. TA.XTplus. (2006): Texture Analysis Application Overview: Confectionery Products. TA.XTplus Texture Analyser, 1-7. https://doi.org/10.1007/978-1-4614-5836-4

58. Thibaudeau, E., Roy, D., St-Gelais, D. (2015): Production of brine-salted Mozzarella cheese with different ratios of $\mathrm{NaCl} / \mathrm{KCl}$. International Dairy Journal 40, 54-61. https://doi.org/10.1016/j.idairyj.2014.07.013

59. USDA (1997): Cream cheese, Neufchatel cheese and related products. The U.S. Department of Agriculture.

60. Walstra, P., Jenness, R. (1984): Dairy chemistry and physics (1st edition). New York: John Wiley \& Sons.

61. Weaver, C. (2013): White Vegetables: A forgotten source of nutrients potassium and health 1-3. American Society for Nutrition 4, 3685-3775. https://doi.org/10.3945/an.112.003533.smoking

62. Wendin, K., Langton, M., Caous, L., Hall, G. (2000): Dynamic analyses of sensory and microstructural properties of cream cheese. Food Chemistry 71 (3), 363-378. https://doi.org/10.1016/S0308-8146(00)00200-4

63. WHO/FAO (2003): Joint WHO/FAO Expert Consultation on Diet, Nutrition and the Prevention of Chronic Diseases. WHO Technical Report Series. Vol. 916.

64. WHO - World Health Organization (2012): Guideline: sodium intake for adults and children, 1-46. Retrieved from http://www.who.int/nutrition/publications/guidelines/ sodium_intake/en/

65. WHO - World Health Organization (2014): European Food and Nutrition Action Plan 2015-2020, 15-18. Retrieved from http://www.euro.who.int/_data/assets/ pdf_file/0003/294474/European-Food-Nutrition-ActionPlan-20152020-en.pdf?ua $=1$ 